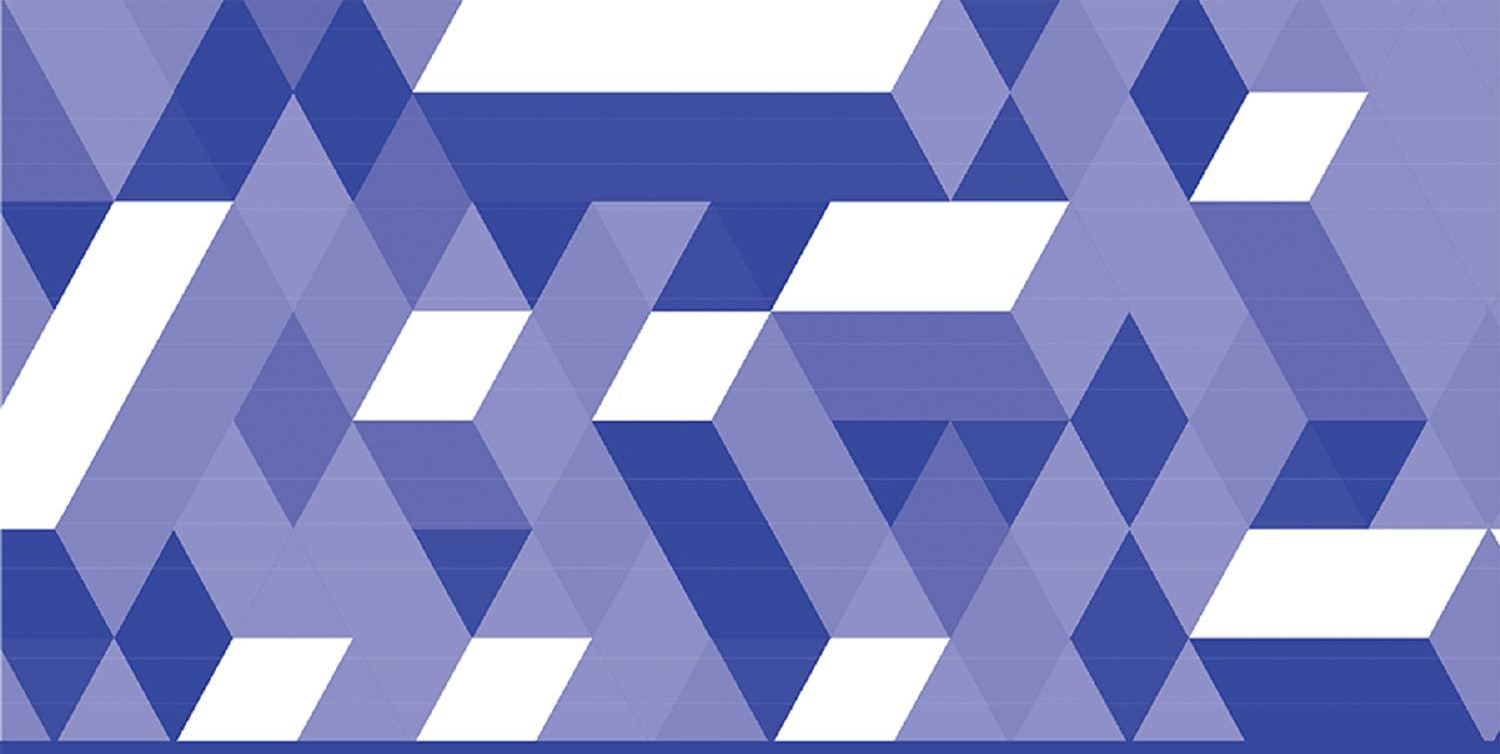

Routledge Studies in New Media and Cyberculture

\title{
FREE SOFTWARE, THE INTERNET, AND GLOBAL COMMUNITIES OF RESISTANCE
}

Sara Schoonmaker

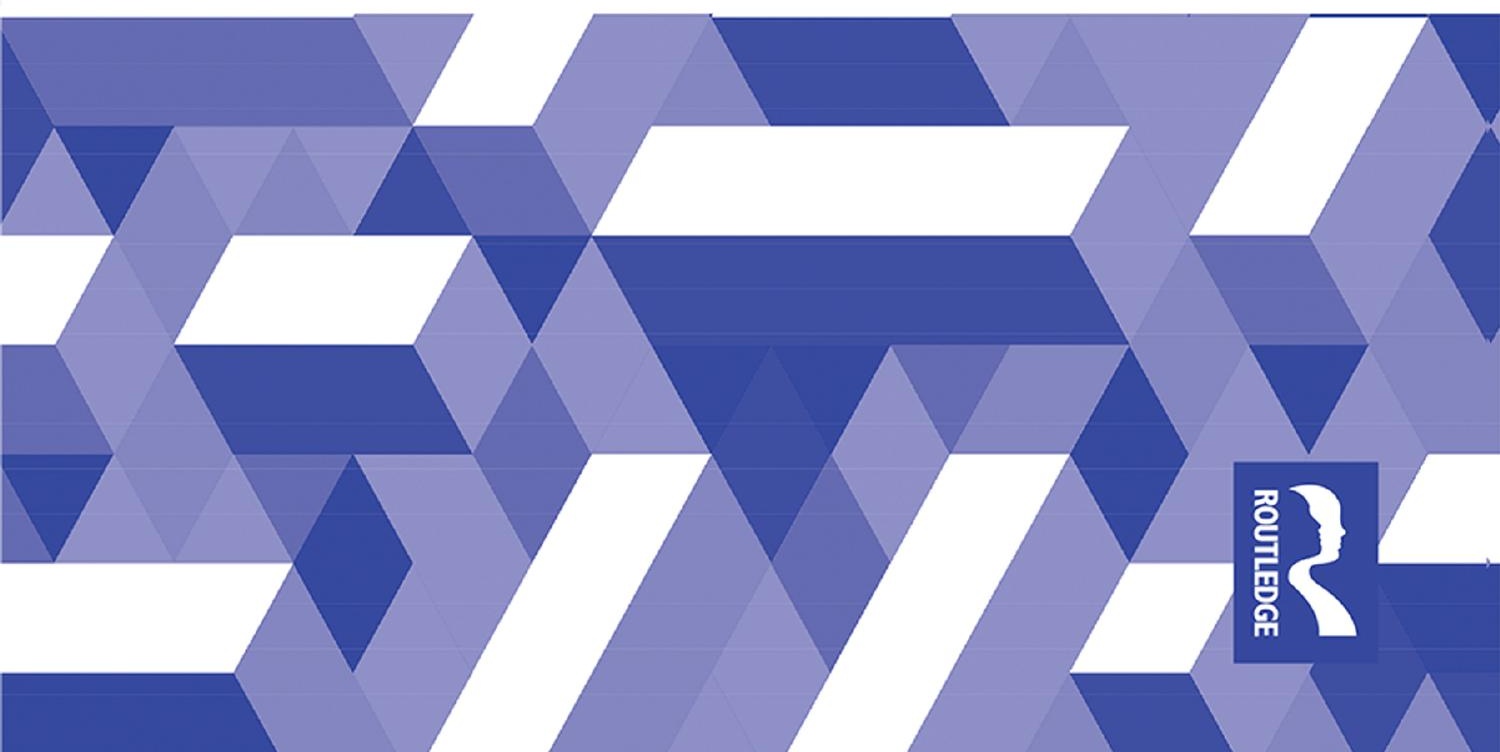




\section{Free Software, the Internet, and Global Communities of Resistance}

This book explores software's pivotal role as the code that powers computers, mobile devices, the Internet, and social media. Creating conditions for the ongoing development and use of software, including the Internet as a communications infrastructure, is one of the most compelling issues of our time. Free software is based upon open-source code, developed in peer communities as well as corporate settings, challenging the dominance of proprietary software firms and promoting the digital commons. Drawing upon key cases and interviews with free software proponents based in Europe, Brazil, and the U.S., the book explores pathways toward creating the digital commons and examines contemporary political struggles over free software, privacy, and civil liberties on the Internet that are vital for the commons' continued development.

Sara Schoonmaker is Professor of Sociology at the University of Redlands, USA. 


\section{Routledge Studies in New Media and Cyberculture}

For a full list of titles in this series, please visit www.routledge.com

32 Citizen Participation and Political Communication in a Digital World

Edited by Alex Frame and Gilles Brachotte

33 Feminism, Labour and Digital Media

The Digital Housewife

Kylie Jarrett

34 The Politics of Ephemeral Digital Media

Permanence and Obsolescence in Paratexts

Edited by Sara Pesce and Paolo Noto

35 Studying Digital Media Audiences

Perspectives from Australasia

Edited by Craig Hight and Ramaswami Harindranath

36 Between the Public and Private in Mobile Communication

Edited by Ana Serrano Tellería

37 Performing Digital Activism

New Aesthetics and Discourses of Resistance

Fidèle A. Vlavo

38 Online Activism in Latin America

Edited by Hilda Chacón

39 Becoming-Social in a Networked Age

Neal Thomas

40 Free Software, the Internet, and Global Communities

of Resistance

Sara Schoonmaker 


\section{Free Software, the Internet, and Global Communities of Resistance}

Sara Schoonmaker

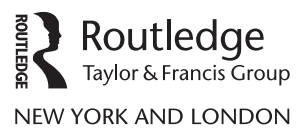


First published 2018

by Routledge

711 Third Avenue, New York, NY 10017

and by Routledge

2 Park Square, Milton Park, Abingdon, Oxon OX14 4RN

Routledge is an imprint of the Taylor \& Francis Group, an informa business

(C) 2018 Taylor \& Francis

The right of Sara Schoonmaker to be identified as author of this work has been asserted by her in accordance with sections 77 and 78 of the Copyright, Designs and Patents Act 1988.

All rights reserved. No part of this book may be reprinted or reproduced or utilised in any form or by any electronic, mechanical, or other means, now known or hereafter invented, including photocopying and recording, or in any information storage or retrieval system, without permission in writing from the publishers.

Trademark notice: Product or corporate names may be trademarks or registered trademarks, and are used only for identification and explanation without intent to infringe.

Library of Congress Cataloging-in-Publication Data

CIP data has been applied for.

ISBN: 978-1-138-94298-1 (hbk)

ISBN: 978-1-315-67278-6 (ebk)

Typeset in Sabon

by codeMantra 
To Hazel, Susan, Avery - mother, sister, daughter 


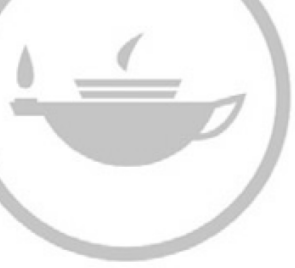

Taylor \& Francis Taylor \& Francis Group

http://taylorandfrancis.com 


\section{Contents}

Acknowledgments ix

1 Hiding in Plain Sight: Software, Surveillance, and Capitalism in Everyday Life

2 Coding the Digital Commons: Foundations in Free Software and the Emerging Internet

3 From Markets to Commons: Free Software as Catalyst for Change

4 Forking toward the Commons: Struggles to Sustain Freedom through Organizational Change

5 Software Politics: Building Communities to Defend Software Freedom

6 Internet Politics: Organizing for Net Neutrality and Civil Liberties

7 Global Communities of Resistance and the Digital Commons

References 


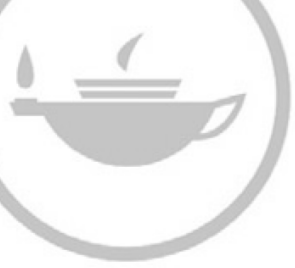

Taylor \& Francis Taylor \& Francis Group

http://taylorandfrancis.com 


\section{Acknowledgments}

Writing this book has been a journey into the social worlds of diverse international communities. In many ways, the fieldwork for this project mirrored the communities themselves. I benefitted from the web of connections between community participants around the world, and from their generous ethic of sharing information, time, and work. I greatly appreciate all of the free software and net neutrality participants who shared their ideas and experiences with me, as well as their openness to putting me in touch with others in their communities that they thought could contribute to the project. Faculty Research Grants from the University of Redlands provided funds to support the research. The reviewers at Routledge offered invaluable feedback that allowed me to improve the manuscript.

Since I began the research for this project in 2006, many people have provided insights and support that helped me to develop the work. My colleagues and friends in the Sociology and Anthropology department and the Johnston Center for Integrative Studies at the University of Redlands provided fertile ground to push intellectual boundaries and develop my thinking. I benefitted from discussing draft chapters of the book with the perceptive students in my Spring 2017 Johnston seminar, that began as Consume the Local/Hack the Global and metamorphosed into Sustainable Alternatives to Capitalism. Choice interventions and camaraderie came from Victoria Bernal, Janet Boguslaw, Jon Cruz, Tess Cruz, Karen Derris, Lorenzo Garbo, Pierre-Amiel Giraud, Avery Gordon, Dorene Isenberg, Padma Kaimal, Sawa Kurotani, Sharon Lang, Penny McElroy, Jennifer Nelson, Laura Robinson, Bill Rocque, Andy Rotter, Christiana Soares de Freitas, Pat Wasielewski, and Tekle Woldemikael. During the final stretch of the writing process, Franco Gasperoni challenged me to rearticulate the transformative significance of free software as a new form of property.

At pivotal times and places, strategic emotional backing came from Jon Arellano-Jackson, Chris Beach, Porsha Beed, Steve Bromer, Krista Comer, Sanjay Carter-Rau, Nick Fisher, Barbie and Loring Fiske-Phillips, Debbie Gardner, Kaye Gates, Marilyn Golden, Sharon Graff, Lynn Hanna, Jim Hood, Aaron Johnson, Jill Kirchner-Rose, Nancy Lemon, 
Barb Lord, Leela MadhavaRau, Heidi Malone, Joy Manesiotis, Andrés Mares-Muro, Ann Morrill, Milton Ospina, Jen Ramos, Karen Rose, Renée Rosen-Rager, Peter Schoonmaker, Casandra Smith, Caley Soury, Denise Spencer, Nick Swensen, Georgia and Rick Sforza, Sara Beth Terrell, and Gavin and Tricia Thrasher.

All along the way, my daughter Avery showered me with love and helped me to find clarity with her incisive artist's sensibility. Susan Schoonmaker extended sisterly solidarity and fond companionship, which was especially dear after the deaths of our parents, Ted and Hazel Schoonmaker. Ted and Hazel's loving commitment to community and justice are with me always and helped me to recognize the profound significance of building the commons. The progressive community at Redlands United Church of Christ was a continuing source of support, music, and welcome. My extended Osajima, Schoonmaker, and chosen families provided gatherings full of delightful food, chaos, and connection. My life partner and in-house editor, Keith Osajima, offered his brilliant mind, generous spirit, abiding love, and sense of adventure. Thanks, as always, for helping me to mix work so thoroughly with pleasure. 


\section{Hiding in Plain Sight \\ Software, Surveillance, and \\ Capitalism in Everyday Life}

Wherever you are in your daily travels, pause and take a look around. Even if you are trekking Africa's highest mountain, summiting Mount Kilimanjaro, it is likely that software is hiding in plain sight. You are probably equipped with state-of-the-art hiking gear, including a handheld Global Positioning System (GPS) unit that receives information from satellites and atomic clocks to find the location of the device and display it on a map. Your device locks onto several satellites, which can locate anyone on earth. It stores and locates waypoints to help you navigate the trail, or find your way back to camp. Your GPS unit offers a range of data, from maps to coordinates of elevation; latitude and longitude; temperature; distances and elevation; barometric pressure; sunrise, sunset, moonrise, and moonset; and logs of trip data for up to 48 hours. It allows you to send messages to similar devices, facilitating contact with other hikers if you get separated. At the end of the day, you may use the device for entertainment, playing geolocation games such as geocaching.

For those of us with more mundane pursuits, software is embedded in myriad activities. We are usually in range of cell phone towers emitting signals that smartphones can access. Indeed, for most of us, our smartphones are comparable to the hikers' handheld GPS systems. The phones themselves, as well as most of the apps, have GPS tracking to monitor where we are. They provide us with information about restaurants, ATM machines, gas stations, cultural attractions, and other sites along our path. Significantly, however, these phones simultaneously collect data about us. They collect data on where we go, what we spend our money on, what we look up on the Internet, the music we listen to, the people we text or email, and more. For users of social media, they document our posts, our photos, our likes, and other reactions to events and people. While hikers use handheld GPS devices to plot treks, consumers in towns and cities use smartphones to navigate our lives.

Wearable digital technologies such as smart watches and activity or fitness trackers collect data about our health and activity. These data document the number of steps we walk or run, our heart rate, sleep patterns, the steps we climb, and the calories we consume. Consumers employing such devices actively collect data about our physical activity, syncing the 


\section{Hiding in Plain Sight}

devices to our computers or smartphones to track long-term trends in our health metric data. In the process, Turkle (2015) views these consumers as developing an algorithmic or quantified self, treating bodies as computational objects, as sources of data. She urges us to reflect on the kinds of authority we give such technologies to shape our views of ourselves, our bodies, and our minds. For example, when we as consumers use such technologies, we may develop habitual ways of thinking about ourselves in terms of quantifiable units and achievements that can be scored. Such a process of quantifiable scoring implies that we can understand ourselves in those terms, tracking our progress over time.

Software is hiding in plain sight in cars. In 1977, General Motors (GM) introduced the first embedded software into its Oldsmobile Toronado model. By 1981, GM had integrated about 50,000 lines of software code to facilitate engine control in its diverse range of domestic passenger car models. It started a trend for other car manufacturers to follow. Since about 2000, software has powered new developments in cars, so that even basic models of cars include dozens of microprocessors and microcontrollers. Higher-end cars run on millions of lines of software code that monitor and control systems ranging from airbags to power trains (Madden 2015; Walls 2016).

Software is increasingly integrated into many objects in our homes, from microwaves to televisions, thermostats, "smart" toys, printers, and fax machines. Samsung markets the Family Hub smart refrigerator as a center of family life, allowing consumers to organize calendars, food shopping, watching movies, and listening to music. While such refrigerators are currently limited to the high end of the market, over the next decade, software will increasingly be integrated into a broader range of refrigerator models.

Smart speakers, or digital assistants, like Google Home and the Amazon Echo allow consumers to set alarms, stream music, podcasts, or audiobooks and access data on weather, traffic, and more. Amazon made the Echo widely available in the U.S. in 2015, expanding to Canada and the United Kingdom in 2016. The Echo can serve as a home automation hub, controlling several smart devices using the Alexa voice-controlled intelligent personal assistant service. Similar to the iPhone's Siri assistant, Microsoft's Cortana, and the "OK Google" voice recognition feature, the Echo is designed to respond to voice commands.

The prevalence of software in the above range of devices poses questions about privacy and surveillance. For example, since the Amazon Echo is continually listening and often recording, privacy advocates warn that it is vulnerable to surveillance. A company like Amazon could retain data recorded by all Echo users and potentially make that data available to other corporations or to government agencies such as law enforcement. Moreover, it is possible to gain remote access to a device like Echo to listen to private conversations. Similar to privacy concerns 
related to webcams on laptops, such devices are vulnerable to remote recording by criminals or domestic surveillance by government intelligence agencies.

Such privacy concerns arose in 2017, when Mattel began marketing Aristotle, a voice-activated baby monitor that serves as a digital nanny. Mattel provided information about the product for an online article in CISION PR Newswire (2017), describing Aristotle as "designed with a specific purpose and mission: to aid parents and use the most advanced AI [Artificial Intelligence]-driven technology to make it easier for them to protect, develop, and nurture the most important asset in their home - their children." Mattel developed the Aristotle platform by partnering with Microsoft to create an Artificial Intelligence (AI) system geared toward babies, as well as older children. The AI system integrates Microsoft Cognitive Services, as well as search capabilities through the Bing search engine. Aristotle includes a hub with a smart light system, including lights for reading and diaper changing, as well as a night light. Moreover, Aristotle includes multiple color lights "specifically designed as a dynamic feedback system tied to the AI" (CISION PR Newswire 2017). To develop this AI hub, Mattel partnered with Qualcomm Technologies. The corporate designers integrated a Wi-Fi camera with object recognition, so that Aristotle can turn on a lullaby and adjust the room's lighting if a baby starts to cry. These designers included features for toddlers and older children, so that Aristotle's lights turn color during interactive sessions. In these sessions, Aristotle asks the child questions; if the child answers correctly, the lights turn green. From Mattel's perspective, "Aristotle is designed to comfort, entertain, teach, and assist during each developmental state - evolving with a child as their needs change from infancy to adolescence" (CISION PR Newswire 2017).

Consumer advocacy groups such as the Campaign for a CommercialFree Childhood (CCFC) (2017) critiqued the Aristotle platform as engaging in surveillance. They viewed the device as a potential threat to privacy, since it could collect and store data about children's activities. Since Aristotle is linked to other applications and online retailers, that data can be shared with corporations and used for targeted advertising to children and their families.

Indeed, from Aristotle to the Echo, from smartphones to cars, televisions, and numerous "smart" objects in our lives, software is hiding in plain sight. Its pervasive presence raises questions about who controls that software, as well as the massive amounts of data it is used to collect about us. Edward Snowden (2016) argues that many consumers are concerned about whether their devices are secure from potential intrusions on their privacy. At the same time, however, they may not consider potential problems with control over those devices. For example, iPhones are known for their reliability and security. Consumers may use them with a sense of confidence that Apple will protect their privacy and 


\section{Hiding in Plain Sight}

provide a reliable, secure device. Despite this security, however, Apple routinely pushes software updates that change the configuration of the phones. Snowden (2016) challenges us to consider whether a device is truly secure when we do not know what it is doing. If we lack the knowledge to understand how it is configured, or the option to make choices about that configuration, we lack control over it. We simply consume the device as a "black box," trusting the corporation to set it up for us.

Software thus raises questions about knowledge, power, and control. Many of those questions are linked to surveillance, since software enables the collection of data about our activities, our health, and our relationships. These data are vulnerable to surveillance, posing potential threats to civil liberties such as the right to privacy. Moreover, these data can be accessed by corporations to target us with advertising. Such data are central to marketing and profit-making in contemporary capitalism. As Columbia University law professor and privacy advocate Eben Moglen (2011) argues,

Software is what the 21st century is made of. What steel was to the economy of the 20th century, what steel was to the power of the 20 th century, what steel was to the politics of the 20th century, software is now. It is the crucial building block, the component out of which everything else is made, and, when I speak of everything else, I mean of course freedom, as well as tyranny, as well as business as usual, as well as spying on everybody for free all the time.

To understand the significance of software's pervasive presence in everyday life, we thus need to analyze software as central to processes of production, marketing, and other aspects of social, cultural, and political life in contemporary capitalism. As software hides in plain sight, processes of surveillance and capitalist production are even more deeply hidden. Exploring the connections between software, surveillance, and capitalism is key to grasping contemporary relations of power, as well as strategies for resistance and transformation.

\section{Informational Capitalism and Globalization}

Contemporary examples of the ubiquity of software in daily life are an acceleration and intensification of the dynamics of capitalist development that scholars have analyzed for many years. We can understand the current significance of software more fully when we place it in the context of these historical dynamics. World systems theorists chronicle the development of capitalism over a span of 500 years, through cycles of expansion of world trade and production, as well as crises of overaccumulation and competition (Wallerstein 1974, 1999; Arrighi 1999). Marx and Engels highlight the nature of capitalism as a global system, where 
the process of colonial expansion laid the foundation for the development of a world market. In the Communist Manifesto, they argue that

The market has given an immense development to commerce, to navigation, to communication by land. This development has, in its turn, reacted on the extension of industry; and in proportion as industry, commerce, navigation, railways extended, in the same proportion the bourgeoisie developed, increased its capital, and pushed into the background every class handed down from the Middle Ages.

(Accessed June 1, 2017, www.marxists.org/archive/marx/ works/1848/communist-manifesto/ch01.htm\#007)

Capitalism is fraught with contradictions, rooted in the dynamics of the profit motive that push capital to constantly seek new markets and ways to exploit human and natural resources.

Communications and transport played a key role in facilitating capitalism's historical development as a global system. Since the midnineteenth century, capitalist enterprises operating in different parts of the world exchanged information through communications systems, from the telegraph to the telephone and eventually the Internet (Hirst and Thompson 1999). As Murdock $(2014,138)$ argues, "[c]apitalism has always relied on advanced communications systems to track, collate, and co-ordinate the dispersed production and consumption activities it sets in motion." In the chapter on capital in the Grundrisse Notebook V, Marx (1973) discusses how communications and transportation systems facilitate processes of capital circulation and play a key role in capitalism's global dynamic. He argues that

while capital must on one side strive to tear down every spatial barrier to intercourse, and conquer the whole earth for its market, it strives on the other side to annihilate this space with time, i.e. to reduce to a minimum the time spent in motion from one place to another.

(Marx 1973, 539)

This dynamic accelerates as capital develops on a global scale. According to Marx, as capital increasingly expands into the international market, "which forms the spatial orbit of its circulation, the more does it strive simultaneously for an even greater extension of the market and for greater annihilation of space by time" (Marx 1973, 539).

Capital thus pursues the construction of communications and transportation systems to create the conditions for commodities to circulate on the market. Building upon this analysis, we can understand struggles by corporations to annihilate space with time by promoting state-of-theart means to communicate about their operations, as well as to transport 


\section{Hiding in Plain Sight}

commodities. Such innovations facilitate what Harvey $(1999,118)$ calls "successive waves of time-space compression." The importance of communications and transportation thus extends from early sea routes and highways to contemporary struggles to establish the political conditions to access the Internet.

Indeed, since the 1970s, the convergence of telecommunications and computing made digital technologies increasingly central to economic, political, social, and cultural life. This convergence eventually made it possible for the Internet to become a vehicle for both communications and the transport of digital commodities, as consumers downloaded music and other products and services in digital form (Schoonmaker 1993, 1994, 2002). Corporations, governments, producers, and consumers rely on access to electronic information to conduct their major activities. To grasp this increasing centrality of information to capitalism on a global scale, Castells (1996) refers to it as global informational capitalism. Fuchs $(2016,2)$ highlights informational capitalism as one of capitalism's multiple dimensions, arguing that "[c]ontemporary capitalism is an informational capitalism just like it is a finance capitalism, imperialist capitalism, crisis capitalism, hyper-industrial capitalism (the importance of fossil fuels and the mobility industries), etc." Fuchs (2014) notes that information technologies, science, theoretical knowledge, and knowledge labor constitute key productive forces of informational capitalism. As Sassen $(2005,54)$ argues, information superhighways bring "higher levels of control and concentration in the global market."

Informational capitalism is thus one of capitalism's multiple dimensions. It is constructed through processes of struggle, within the broader context of neoliberal globalization as the current dominant form of capitalism. As Fuchs $(2014,44)$ argues, neoliberalism is a "mode of existence" or "regime" of global capitalism. Since the U.S. government has strongly promoted this neoliberal regime, it is also known as the "Washington Consensus" (Langman 2012). Harvey $(2005,2)$ traces the rise of neoliberalism since the late 1970s, as a system "characterized by strong private property rights, free markets, and free trade." Neoliberal globalization, or what McMichael $(2000,2017)$ calls the globalization project, thus has a number of key characteristics. Economically, interests of transnational corporations take priority over those of smaller, local firms. Politically, trade agreements or other legal conditions often support the proprietary interests of transnational firms or governments in the global North rather than small producers or grassroots groups, particularly in the global South. Culturally, values of sharing and community access tend to be subordinated to values prioritizing high levels of commodity consumption.

Equally important, neoliberalism is constructed through discourse, or narratives of power and knowledge. Building on Foucault (1978), I employ a poststructuralist perspective that power and knowledge are 
inextricably linked through discourse. In discourse, social actors draw upon cultural values and language that resonate with particular ways of understanding the social world. Through discourse, they articulate their positions on the key issues at stake (Foucault 1978; Escobar 1995; Schoonmaker 2002). For example, the discourse of neoliberalism is rooted in the assumption that free trade is the most rational approach to structuring global markets, largely because it protects the proprietary interests of corporations in maximizing their profits. Proponents of this discourse depict any state attempts to regulate markets through protections for local industries, workers, or environmental health as barriers to trade that undermine global economic growth. Over the years, such proponents have included the World Bank, the International Monetary Fund, and U.S. presidents such as Ronald Reagan, George H.W. Bush, Bill Clinton, George W. Bush, and Barack Obama. Support for the neoliberal discourse is sometimes partial and complicated; such was the case with President Obama's advocacy for the neoliberal Trans-Pacific Partnership (TPP) global trade agreement and simultaneous support for some protections for the environment and local industry.

Escobar (1995) highlights the importance of understanding the economy as a discourse imbued with cultural values and meanings. People both respond to and are shaped by these cultural meanings as they participate in processes of socialization and enculturation. Escobar (1995) thus views the economy as a cultural production, through which we become particular kinds of people who value practices like economic productivity and success, as well as engaging in those practices through work and consumption. A poststructuralist perspective thus allows us to understand economic and political structures as constructed through discourse as forms of knowledge and understanding, as well as through material practices. In the next chapter, I discuss the key role of the proprietary, freedom, and sovereignty discourses in the development of the digital commons. Indeed, the proprietary discourse is closely linked to the neoliberal discourse, since both are rooted in values of protecting corporate proprietary interests by boosting profits and expanding into new markets.

\section{Global Communities of Resistance}

Due to their centrality to informational capitalism and neoliberal globalization, software and the Internet have become key terrains of struggle over the past decades. Free software and net neutrality advocates work simultaneously to create alternatives to informational capitalism and neoliberal globalization. They forge alternatives rooted in the freedom to share and collaborate, as well as respect for sovereignty and civil liberties like the rights to free speech and privacy. Like other projects seeking to develop alternative forms of globalization from below, they mobilize participants to resist neoliberal globalization (Della Porto, Andretta, 


\section{Hiding in Plain Sight}

and Mosca 2006; Langman 2012). In the process, free software and net neutrality advocates develop communities that involve what Sassen $(2005,54)$ calls "distributive outcomes - greater participation of local organizations in global networks."

These communities resonate with Portes' $(2000,254)$ conception of globalization from below, where common people respond to neoliberalism by "creat[ing] communities that sit astride political borders and that, in a very real sense, are 'neither here nor there' but in both places simultaneously." While some movements promoting globalization from below focus on environmental justice, or the rights of the poor, workers, women, immigrants, or indigenous people, free software and net neutrality advocates struggle to promote the development of free software and conditions for equal access to the Internet. They thus focus on questions central to informational capitalism.

Portes (2000) highlights the power of such diverse transnational efforts to develop alternative forms of globalization from below. He argues that

[m]ultinational elites and national governments may believe that the process of transnationalization is still too feeble to pose any significant challenge to the status quo. In reality, the tiger may have already left the cage, and there would be little point in closing it after him.

(Portes 2000, 266)

Throughout this book, I explore a range of ways that free software and net neutrality communities engage in local actions linked to global projects, thus developing alternative forms of globalization from below. They are examples of "tigers" that have created global communities of resistance. These communities challenge neoliberalism and informational capitalism with vibrant forms of peer-produced software, free culture, and other contributions to the digital commons. Like other projects seeking to develop alternative forms of globalization from below, they mobilize participants to "redress their grievances and foster more democratic, participatory, humanistic, egalitarian, ecologically sound alternatives" to neoliberalism (Langman 2012, 865).

\section{The Argument}

In the following pages, I examine the ways that global free software and net neutrality communities of resistance challenge neoliberalism and informational capitalism. These challenges are rooted in a common goal of developing a digital commons, where all participants can access, use, modify, and share software and the Internet. In the next chapter, I highlight the meaning and significance of the commons, as well as the methods used in this study. I analyze the development of the digital commons, based on two sets of struggles. First, free software advocates in 
the U.S. created free software as an alternative form of property distinct from private property. Second, researchers in Brazil advocated opening up access to emerging global computer networks. These two groups did not know each other or coordinate their activities; however, they laid the foundations for the development of the digital commons. Indeed, the digital commons are based upon free software and an open, decentralized Internet. Proponents of the digital commons continued to develop it after 2001, by forming Creative Commons and Wikipedia.

As participants in diverse free software projects collaborate to produce the software, they develop global communities. In Chapter 3, I analyze the possibilities and challenges involved with developing free software communities by comparing the Debian and Drupal projects. Both projects involve participants from around the world who coordinate their work over the Internet. They engage in myriad activities, from coding the software itself to writing documentation and translating programs into different languages to make them accessible to wider groups of people. Both projects involve a mix of forms of software production, combining work by unpaid peer producers with work by paid developers. The key difference between the projects is the nature of the software that they produce. Debian software allows developers to include proprietary elements that restrict users' freedoms. Drupal software is free software, contributing to the digital commons by allowing users freedom to access, modify, and share the software without restrictions. Moreover, Drupal project participants made conscious efforts to expand their project beyond North America and Europe into the global South. In the process, they forged a global community that implicitly resisted neoliberalism and informational capitalism. They did not explicitly organize political resistance; however, by building free software and extending their global community, they created an alternative form of globalization from below.

Free software communities thus play key roles in developing the digital commons. In Chapter 4, I explore the ways that communities work to organize themselves to protect the freedoms of their participants. I focus on the case of LibreOffice and The Document Foundation, whose participants created the project by splitting off from the OpenOffice. org community. They were concerned about increasing corporate influence over OpenOffice.org that could undermine the freedom to access, modify, and share the software. They created an innovative new organizational structure to support these freedoms and to work for values of digital inclusion central to the digital commons. In the process, they also constituted an implicit global community of resistance to neoliberalism.

Free software itself, as well as the community organizations required to produce it, thus contribute to developing the digital commons. Because software is central to production in informational capitalism, however, conditions for software use and production become sites for political struggles. Corporations and governments often promote the interests of 
proprietary software, thus undermining free software. In response to these threats, free software activists mobilize to protect and defend the conditions to produce free software. In Chapter 5, I highlight the efforts by free software activists in France to organize such political action, building alliances with free software activists in other parts of Europe as well as the U.S. In the process, these activists forged a free software global community of resistance with an explicitly political focus.

As noted above, the Internet is an equally important foundation of the digital commons as free software. Moreover, both software and the Internet are key productive forces for informational capitalism. As in the case of software, corporations and governments often promote proprietary interests in accessing the Internet. In response, net neutrality activists struggle to shape the political conditions for Internet access. They fight to protect the Internet as an open, decentralized system that all users are free to access on an equal basis. In the process, they struggle against corporate and government practices that prioritize profit and collect data about consumers and citizens. They view many of these practices as forms of surveillance that threaten civil liberties and democratic institutions. In response to these threats, net neutrality activists employ strategies to gain greater control over the existing telecommunications infrastructure. They seek to evade practices of surveillance, as well as to devise alternative telecommunications infrastructures of their own. In the process, they create explicit global communities of resistance to defend the Internet as a basis for the digital commons.

In the following chapters, I thus explore key dynamics of struggle over neoliberalism and informational capitalism. I highlight examples of key projects and activist strategies that contribute to the development and defense of the digital commons. These projects are beautifully varied, created by participants in many countries around the world. They are diverse and global. They are not intended to be exhaustive, however; there are a multitude of other such projects around the world. Over time, such projects change, as advocates of free software and net neutrality continue to design inventive ways to build, share, and transform software and the Internet. As danah boyd $(2014,27)$ notes in her study of teen use of social media, these technological platforms are "moving landscape[s]." Like social media, particular free software projects or activist strategies will change over time; however, "the core principles and practices.... are likely to persist" (boyd 2014, 27). Indeed, in the case of implicit and explicit free software and net neutrality global communities of resistance, they are likely to persist because they target core dynamics of neoliberalism and informational capitalism. Until those systems are radically transformed, such communities are likely to continue to create imaginative ways to contribute to developing the digital commons. 


\section{References}

Adams, Tracey L. and Erin I. Demaiter . "Skill, education and credentials in the new economy: The case of information technology workers." Work, Employment and Society 22, no. 2 (2008): 351-362.

Adler, Emanuel . The Power of Ideology: The Quest for Technological Autonomy in Argentina and Brazil. Berkeley: University of California Press, 1987.

Andrejevic, Mark . iSpy: Surveillance and Power in the Interactive Era. Lawrence, KS: University of Kansas Press, 2007.

Amadeo, Ron . "Google's iron grip on Android: Controlling open source by any means necessary." ars technica. Accessed July 28, 2015.

http://arstechnica.com/gadgets/2013/10/googles-iron-grip-on-android-controlling-opensource-by-any-means-necessary/1/, 2013.

Arrighi, Giovanni . "Globalization, State Sovereignty, and the Endless Accumulation of Capital." In States and Sovereignty in the Global Economy, edited by David A. Smith , Dorothy J. Solinger, and Steven C. Topik , 53-73. London: Routledge, 1999.

Article 19 . "Marco Civil da Internet: seis meses depois, em que pé que estamos?" Accessed February 2, 2017. http://artigo19.org/blog/2015/01/23/analise-marco-civil-da-internet-seismeses-depois-em-que-pe-que-estamos/, 2015.

Azzam, Amin , David Bressler, Armando Leon, Lauren Maggio , Evans Whitaker , James Heilman, Jake Orlowitz, Valerie Swisher , Lane Rasberry, Kingsley Otoide, Fred Trotter , Will Ross, and Jack McCue. "Why medical schools should embrace Wikipedia: Final-year medical student contributions to Wikipedia articles for academic credit at one school."

Academic Medicine 92 (2017): 194-200.

Bacon, Jono . The Art of Community. O'Reilly Media: Sebastapol, 2009.

Bangeman, Eric . "French Legislation Might Chase iTMS out of the Country." Ars Technica. Accessed July, 30, 2009. http://arstechnica.com/old/content/2006/03/6371.ars, 2006a.

Bangeman, Eric . "French Parliament Passes DRM Bill. Will Apple Bolt?" Ars Technica. Accessed July 29, 2009. http://arstechnica.com/old/content/2006/03/6428.ars, 2006b.

Bauwens, Michel . "Class and capital in peer production." Capital \& Class 33 (2009): 121-141.

Benkler, Yochai . The Wealth of Networks: How Social Production Transforms Markets and Freedom. New Haven: Yale University Press, 2006.

Benkler, Yochai . "Commons and growth: The essential role of open commons in market economies." University of Chicago Law Review 80 (2013a): 1499-1555.

Benkler, Yochai . "Practical anarchism: Peer mutualism, market power, and the fallible state." Politics \& Society 41 (2013b): 213-251.

Benkler, Yochai . Nation as Network: Diaspora, Cyberspace \& Citizenship. Chicago: The University of Chicago Press, 2014.

Blum, Andrew . Tubes: A Journey to the Center of the Internet. New York: HarperCollins Publishers, 2012.

Bollier, David . Viral Spiral: How the Commoners Built a Digital Republic of Their Own. New York: The New Press, 2008.

Bollier, David and Silke Helfrich, eds., The Wealth of the Commons: A World Beyond Market and State. Amherst, MA: Levellers Press, 2012.

boyd, danah . It's Complicated: The Social Lives of Networked Teens. New Haven: Yale University Press, 2014.

Boyle, James. The Public Domain: Enclosing the Commons of the Mind. New Haven: Yale University Press, 2008.

Buttar, Shahid . "Grassroots digital rights alliance expands across U.S." Accessed March 24, 2017. https://eff.org/deeplinks/2016/11/grassroots-digital-rights-alliance-expands-across-us, 2016.

Campaign for a Commercial-Free Childhood . "Don't let Mattel's new "digital nanny" trade children's privacy for profit." Accessed July 27, 2017.

http://commercialfreechildhood.org/action/dont-let-mattels-new-digital-nanny-trade-childrensprivacy-profit, 2017. 
Candidats.fr . Accessed June 20, 2009. http://www.candidats.fr/index.php/2007/01/27/11principe-des-mesures-techniques-, 2007.

Capek, P.G. , S.P. Frank , S. Gerdt, and D. Shields . "A history of IBM's open-source involvement and strategy." IBM Systems Journal 44 (2005): 249-257.

Carvalho, Marcelo Sávio Revoredo Menezes . "A Trajetória da Internet no Brasil: Do Surgimento das Redes de Computadores à Instituição dos Mecanismos de Governança." Master's thesis, Universidade Federal do Rio de Janeiro (UFRJ), 2006.

Castells, Manuel . The Rise of the Network Society. Oxford: Blackwell, 1996.

Castells, Manuel . Communication Power. New York: Oxford University Press, 2009.

Chadwick, Andrew . Internet Politics: States, Citizens, and New Communication

Technologies. New York: Oxford University Press, 2006.

Champeau, Guillaume. "NKM demande des backdoors contre le chiffrement." Numerama, January 12. Accessed March 16, 2016. http://numerama.com/politique/138264-nkmdemande-des-backdoors-contre-le-chiffrement.html, 2016a.

Champeau, Guillaume . "Chiffrement: le gouvernement rejette les backdoors." Numerama, January 13. Accessed March 16, 2016. http://numerama.com/politique/138689-chiffrementle-gouvernement-rejette-les-backdoors.html, 2016b.

Chan, Anita Say . "Coding free software, coding free states: Free software legislation and the politics of code in Peru." Anthropological Quarterly 77 (2004): 531-545.

Chan, Anita Say . Networking Peripheries: Technological Futures and the Myth of Digital Universalism. Cambridge, MA: MIT Press, 2013.

Chausson, Cyrille . "Free software groups protest France school software deal." Open Source Observatory, February 15. Accessed June 27, 2017.

https://joinup.ec.europa.eu/community/osor/news/free-software-groups-protest-france-schoolsoftware-deal, 2016.

CISION PR Newswire. "Mattel's nabi brand introduces first-ever connected kids room platform in tandem with Microsoft and Qualcomm - Aristotle." Accessed July 27, 2017. http://prnewswire.com/news-releases/mattels-nabi-brand-introduces-first-ever-connectedkids-room-platform-in-tandem-with-microsoft-and-qualcomm---aristotle-300385221.html, 2017.

Claburn, Thomas . "Google's secret patent portfolio predicts gPhone." InformationWeek, September 19. Accessed July 29, 2015. http://informationweek.com/googles-secret-patentportfolio-predicts-gphone/d/d-id/1059389?cid=nl_iwk_daily, 2007.

Coleman, E. Gabriella. "The political agnosticism of free and open source software and the inadvertent politics of contrast." Anthropological Quarterly 77 (2004): 507-519.

Coleman, E. Gabriella . Coding Freedom: The Ethics and Aesthetics of Hacking. Princeton: Princeton University Press, 2012.

Coombe, Rosemary J. and Andrew Herman . "Rhetorical virtues: Property, speech, and the commons on the world-wide web." Anthropological Quarterly 77 (2004): 559-574.

Corbet . "OpenOffice.org community members launch Document Foundation." LWN.net, September 28. Accessed June 10, 2013. http://lwn.net/Articles/407383/, 2010.

Couture, Stéphane and Serge Proulx. "Les Militants du Code." In L'Action Communautaire Québécoise à l'Ère du Numérique, edited by Stéphane Couture, Serge Proulx and Julien Rueff , 14-35. Québec: Presses de l'Université du Québec, 2008.

Currie, Morgan , Christopher Kelty and Luis Felipe Rosado Murillo . "Free software trajectories: From organized publics to formal social enterprises." Journal of Peer Production 3 (2013).

de Laat, Paul B. "Governance of open source software: State of the art." Journal of Management and Governance 11 (2007): 165-177.

Della Porto , Donatella, Massimillano Andretta , and Lorenzo Mosca . Globalization from Below: Transnational Activists and Protest Networks. Minneapolis: University of Minnesota Press, 2006.

Direction Interministerielle des Systemes d'Information et de Communication (DISIC). "Usage du logiciel libre dans l'administration." Paris: République Française, 2012.

Doctorow, Cory . "Harlem Cryptoparty: Crypto matters for \#blacklivesmatter." Accessed July 18, 2017. http://boingboing.net/2015/12/11/harlem-cryptoparty-crypto-mat.html, 2015. 
Doueihi, Milad . La Grande Conversion Numérique. Paris: Seuil, 2008.

Drahos, Peter and John Braithwaite . Information Feudalism: Who Owns the Knowledge Economy? London: Earthscan Publications, 2002.

Electronic Frontier Foundation (EFF). "A history of protecting freedom where law and technology collide." Accessed September 10. https://eff.org/about/history, 2014a.

Electronic Frontier Foundation (EFF) . "Unintended consequences: Sixteen years under the DMCA." Accessed October 12, 2016. https://eff.org/wp/unintended-consequences-16-yearsunder-dmca, 2014b.

Engelfriet, A. "Choosing an open source license." IEEE Software 27 no. 1 (2010): 48-49.

Escobar, Arturo . Encountering Development: The Making and Unmaking of the Third World. Princeton: Princeton University Press, 1995.

Espern, Christophe . "Le projet de loi DADVSI." Presentation at discussion forum "Le droit d'auteur à l'ére numérique." Accessed June 13, 2009. http://carrefour-numerique.citesciences.fr/live/dadvsi_textes.html\#eucd, 2005.

EUCD.INFO . "Pétition demandant le retrait de l'ordre du jour parlementaire du projet de loi DADVSI."' Accessed June 16, 2009. http://eucd.info/petitions/index.php?petition=2, 2005.

Evans, Peter B. "State, capital, and the transformation of dependence: The Brazilian computer case." World Development 14 (1986): 791-808.

Evans, Peter B. "Declining hegemony and assertive industrialization: U.S.-Brazil conflicts in the computer industry." International Organization 43 (1989): 207-238.

Federal Communication Commission, "Report and Order on Remand, Declaratory Ruling, and Order," FCC 15-24. Accessed November 21, 2017.

transition.fcc.gov/Daily_Releases/Daily_Business/2015/db, 2015.

Felten, Edward W. "The digital millenium copyright act and its legacy: A view from the trenches." Journal of Law, Technology \& Policy 21 (2002): 289-293.

Fichman, Pnina and Noriko Hara . "Introduction." In Global Wikipedia: International and Cross-Cultural Issues in Online Collaboration, edited by Pnina Fichman and Noriko Hara, 1-5. New York: Rowman \& Littlefield, 2014.

filhocf . "Agora o BrOffice chama-se LibreOffice." Posted April 5. Accessed June 5, 2013. http://broffice.org/agora_o_bro_chama_libo, 2011.

Fontana, John. "IBM takes aim at Office with free productivity apps." Network World, September 18. Accessed September 26, 2015.

http://networkworld.com/article/2285484/software/ibm-takes-aim-at-office-with-freeproductivity-apps.html, 2007.

Foucault, Michel . The History of Sexuality. Volume I: An Introduction. Trans. Robert Hurley . New York: Vintage Books, 1978.

Freire, Paulo . Pedagogy of the Oppressed. New York: The Seabury Press, 1974.

Freire, Paulo . "Sociotechnical and Political Processes Shaping Digital Democracy in Brazil:

The Case of the Project e-Democracia ." In Inovação, Governança Digital e Políticas Públicas: Conquistas e Desafios para a Democracia, edited by Christiana Soares de Freitas , 31-45. Arraes Editores, 2016.

FSF France . "French Government Lobbied to Ban Free Software." Accessed July 31, 2009. http://www.fsffrance.org/news/article2005-11-25.en.html, 2005.

Fuchs, Christian . "Critique of the Political Economy of Informational Capitalism and Social Media." In Critique, Social Media and the Information Society, edited by Christian Fuchs and Marisol Sandoval , 51-65. New York: Routledge, 2014.

Fuchs, Christian . Reading Marx in the Information Age: A Media and Communication Studies Perspective on Capital Volume I. New York: Routledge, 2016.

Gamalielsson, Jonas and Björn Lundell . "Sustainability of Open Source software communities beyond a fork: How and why has the LibreOffice project evolved?" The Journal of Systems and Software 89 (2014): 128-145.

Gamalielsson, Jonas, Björn Lundell , Jonas Feist, Tomas Gustavsson, and Fredric Landqvist . "On organisational influences in software standards and their open source implementations." Information and Software Technology 67 (2015): 30-43.

Garfield, Larry . Keynote address at DrupalCon Latin America. Accessed July 31, 2017. https://youtube.com/watch?v=-ILILalZr44, 2015. 
Gay, Joshua, ed. Free Software, Free Society: Selected Essays of Richard M. Stallman. Boston: GNU Press, 2002.

Gençer, Mehmet and Búlent Ōzel . "Forking the commons: Developmental tensions and evolutionary patterns in open source software." IFIP Advances in Information and Communication Technology 378 (2012): 310-315.

Ghedin, Rodrigo . "Acabou a confusāo: BrOffice passa a ser LibreOffice no Brasil." Meio Bit, March 18. Accessed June 5, 2013. http://meiobit.com/82603/broffice-libreoffice-brasil/, 2011. González-Barahona, Jesús M. and Gregorio Robles . "Libre software in Europe." In Open Sources 2.0: The Continuing Evolution, edited by C. DiBona, D. Cooper and M. Stone , 161-188. Beijing: O'Reilly, 2006.

Haggerty, Kevin D. and Amber Gazso . "Seeing beyond the ruins: Surveillance as a response to terrorist threats." The Canadian Journal of Sociology 30 (2005): 169-187.

Haggerty, Kevin D. and Richard V. Ericson . "The surveillant assemblage." British Journal of Sociology 51 (2000): 605-622.

Harvey, David . "Time-Space Compression and the Postmodern Condition." In Modernity: Critical Concepts. Volume IV after Modernity, edited by Malcolm Waters , 98-118. London: Routledge, 1999.

Harvey, David . A Brief History of Neoliberalism. Oxford: Oxford University Press, 2005. Hempel, Jessi . "India Bans Facebook's Basics App to Support Net Neutrality." Wired, February 8. Accessed January 20, 2017. https://wired.com/2016/02/facebooks-free-basicsapp-is-now-banned-in-india/, 2016.

Hess, Charlotte and Elinor Ostrom . "Introduction: An Overview of the Knowledge Commons." In Understanding Knowledge as a Commons: From Theory to Practice, edited by Charlotte Hess and Elinor Ostrom , 3-26. Cambridge, MA: The MIT Press, 2006.

Hillenius, Gijs . "Mayor of Munich: 'EU laptops should have LibreOffice or OpenOffice." European Commission Joinup, December 20, 2011. Accessed June 10, 2013.

http://joinup.ec.europa.eu/news/mayor-munich-eu-laptops-should-have-libreoffice-oropenoffice, 2011.

Hillesley, Richard . "LibreOffice - A fresh page for OpenOffice." The H Open. Accessed July 5, 2013. http://h-online.com/open/features/LibreOffice-A-fresh-page-for-OpenOffice1097358.html, 2010.

Hirst, Paul and Grahame Thompson . Globalization in Question. Malden, MA: Blackwell, 1999.

Holt, Douglas B. "Why the Sustainable Economy Movement Hasn't Scaled: Toward a Strategy that Empowers Main Street." In Sustainable Lifestyles and the Quest for Plenitude: Case Studies of the New Economy, edited by Juliet B. Schor and Craig J. Thompson , 202-232. New Haven: Yale University Press, 2014.

IBM Corporation. "IBM Is Committed to Linux and Open Source." Somers, NY: IBM Corporation. Accessed September 29, 2017. https://www-01.ibm.com/common/ssi/cgibin/ssialias?htmlfid=LXB03001USEN, 2008.

Intergovernmental Bureau for Informatics (IBI) . Latin American Regional Meeting on Transborder Data Flows. Rome: Intergovernmental Bureau for Informatics, 1982.

Karanović, Jelena . "Sharing Publics: Democracy, Cooperation, and Free Software Advocacy in France." Ph.D. thesis, New York University, 2008.

Karanović, Jelena . "Contentious Europeanization: The paradox of becoming European through anti-patent activism." Ethnos 75 (2010): 3, 252-274.

Kelty, Christopher M. Two Bits: The Cultural Significance of Free Software. Durham and London: Duke University Press, 2008.

Landzelius, Kyra . "Introduction." In Native on the Net: Indigenous and Diasporic Peoples in the Virtual Age, edited by Kyra Landzelius , 1-42. London: Routledge, 2006.

Langman, Lauren . "Globalization from Below." In The Wiley-Blackwell Encyclopedia of Globalization, edited by George Ritzer , 864-870. Chichester, West Sussex: Wiley-Blackwell, 2012.

Lessig, Lawrence. Free Culture: How Big Media Uses Technology and the Law to Lock Down Culture and Control Creativity. New York: Penguin Press, 2004.

Lessig, Lawrence . Code version 2.0. New York: Basic Books, 2006. 
Lessig, Lawrence . Remix: Making Art and Commerce Thrive in the Hybrid Economy. New York: Penguin Press, 2008.

Lethbridge, Timothy C. , Jorge Díaz-Herrera, Richard J. LeBlanc Jr. and J. Barrie Thompson . "Improving software practice through education: Challenges and future trends." FOSE, 12-28. Future of Software Engineering (FOSE'07), 2007.

Lih, Andrew . The Wikipedia Revolution: How a Bunch of Nobodies Created the World's Greatest Encylopedia. New York: Hyperion, 2009.

Livingstone, Randall . "Immaterial Editors: Bots and Bot Policies across Global Wikipedia." In Global Wikipedia: International and Cross-Cultural Issues in Online Collaboration, edited by Pnina Fichman and Noriko Hara , 7-23. New York: Rowman \& Littlefield, 2014.

Lohninger, Erstellt von Thomas . "How we saved the Internet in Europe." Epicenter. Works. Accessed March 23, 2017.

https://epicenter.works/content/how-we-saved-the-internet-in-europe, 2016.

Lyon, David . "Surveillance, snowden, and big data: Capacities, consequences, critique." Big Data \& Society 1 (2014): 1-13.

Maass, Dave and Rainey Reitman . "EFF's 100-Day Plan." Accessed March 24, 2017. https://eff.org/deeplinks/2017/01/our-100-day-plan, 2017.

Madden, Joe. "How much software is in your car? From the 1977 Toronado to the Tesla P85D." Quantitative Software Management. Accessed July 26, 2017.

http://qsm.com/blog/2015/how-much-software-your-car-1977-toronado-tesla-p85d, 2015. Manijak, Peter . "New certification program addresses growing popularity of Drupal." Go Certify. Accessed January 29, 2016. http://gocertify.com/articles/new-certification-programaddresses-growing-popularity-of-drupal.html, 2014.

Markus, M. Lynne. "The governance of free/open source software projects: Monolithic, multidimensional, or configurational?" Journal of Management and Governance 11 (2007): 151-163.

Marx, Karl . Grundrisse: Introduction to the Critique of Political Economy. New York: Vintage Books, 1973.

Marx, Karl and Friedrich Engels. The Communist Manifesto. Northampton: Pluto Press, 2017.

McKibben, Bill . Deep Economy: The Wealth of Communities and the Durable Future. New York: Henry Holt and Company, 2007.

McMichael, Philip . "Globalisation: Trend or Project?" In Rolan Palan , editor, Global Political Economy: Contemporary Theories, 100-113. London: Routledge, 2000.

McMichael, Philip . Development and Social Change: A Global Perspective. Thousand Oaks, CA: Sage, 2017.

Meyer Maria, Jessica . "Why big government sites run Drupal." Governing.com. Accessed

August 4, 2015. http://governing.com/news/technology/Why-Big-Government-Sites-RunDrupal-.html, 2012.

Moghaddam, Roshanak Zilouchian, Bongen, Kora and Michael Twidale . "Open Source Interface Politics: Identity Acceptance, Trust, and Lobbying." Extended Abstracts on Human Factors in Computing Systems. New York: ACM, 2011.

Moglen, Eben . "Freedom in the cloud: Software freedom, privacy, and security for Web 2.0 and cloud computing." Speech at Internet Society's New York Branch Meeting on February 5. Accessed February 25, 2017. https://softwarefreedom.org/events/2010/isoc-

ny/FreedomInTheCloud-transcript.html, 2010.

Moglen, Eben. "Why political liberty depends on software freedom more than ever." Speech at the Free and Open Source Software Developers' European Meeting on February 5.

Accessed February 25, 2017. https://softwarefreedom.org/events/2011/fosdem/moglen-

fosdem-keynote.html, 2011.

Moglen, Eben . "Snowden and the future, part II; oh, freedom." Accessed February 10, 2017. http://snowdenandthefuture.info/documents.html, 2013a.

Moglen, Eben . "Snowden and the future, part III; the union, may it be preserved." Accessed February 10, 2017. http://snowdenandthefuture.info/documents.html, 2013b.

Moreno, Ana M. , Maria-Isabel Sanchez-Segura, Fuensanta Medina-Dominguez , and Laura Carvajal . "Balancing software engineering education and industrial needs." The Journal of Systems and Software 85 (2012): 1607-1620. 
Murdock, Graham . "Producing Consumerism: Commodities, Ideologies, Practices." In Critique, Social Media and the Information Society, edited by Christian Fuchs and Marisol Sandoval , 125-143. New York: Routledge, 2014.

Murphy, Brian M. The International Politics of New Information Technology. New York: St. Martin's Press, 1986.

Noonan Nyman, Linus . Understanding Code Forking in Open Source Software: An Examination of Code Forking, Its Effect on Open Source Software, and How It Is Viewed and Practiced by Developers. Publications of the Hanken School of Economics. Helsinki, Finland: Hanken School of Economics, 2015.

Noonan Nyman , Linus, Tommi Mikkonen, Juho Lindman and Martin Fougère . "Forking: The Invisible Hand of Sustainability in Open Source Software." Proceedings of SOS 2011:

Towards Sustainable Open Source. Tampere University of Technology. Department of Software Systems. Report 19: 1-6, 2011.

Noonan Nyman , Linus and Tommi Mikkonen . "To fork or not to fork: Fork motivations in SourceForge projects." Open Source Systems: Grounding Research. IFIP Advances in Information and Communications Technology 365 (2011): 259-268.

Noonan Nyman , Linus and Juho Lindman . "Code forking, governance, and sustainability in open source software." Technology Innovation Management Review 3 (2013): 7-12.

O'Mahony, Siobhán . "Nonprofit Foundations and Their Role in Community-Firm Software Collaboration." In Perspectives on Free and Open Source Software, edited by Joseph Feller , Brian Fitzgerald, Scott A. Hissam and Karim R. Lakhani , 393-413. Cambridge, MA: MIT Press, 2005.

Organization for Economic Cooperation and Development (OECD) . Transborder Data Flows and the Protection of Privacy. Paris: Organization for Economic Cooperation and Development, 1979.

Parens, Bruce. "The Open Source Definition." In Opensources: Voices from the Open Source Revolution, edited by Chris DiBona , Sam Ockman , and Mark Stone , 171-188. Beijing: O'Reilly \& Associates, Inc, 1999.

Paul, Ryan . "France's Proposed Copyright Reforms Are More Draconian Than the DMCA." Ars Tecnica. Accessed July 30, 2009. http://arstechnica.com/old/content/2005/12/5729.ars, 2005.

PC World. "The 100 best products of 2010." PC World 28 (2010): 12, 86-90, 92, 94, 96, 98, 100.

Perzanowski, Aaron K. "Evolving Standards \& the Future of the DMCA Anticircumvention Rulemaking." Journal of Internet Law 1:1 (2007).

Phipps, Simon. "Transparency and privacy." Wild Webmink. Accessed September 25, 2015. http://webmink.com/essays/transparent-private/, (2011a).

Phipps, Simon . "OpenOffice.org and contributor agreements." LWN.net, May 20. Accessed September 25, 2015. https://lwn.net/Articles/443989/, (2011b).

Pillar, C. "How piracy opens doors for windows." Los Angeles Times, April 9, C1, C10, 2006. Pinho, Larissa and Katitza Rodriguez . "Marco Civil Da Internet: The Devil in the Details." Electronic Frontier Foundation, Deeplinks Blog, February 25. Accessed January 27, 2017. https://eff.org/deeplinks/2015/02/marco-civil-devil-detail. 2015.

Portes, Alejandro . "Globalization from Below: The Rise of Transnational Communities." In The Ends of Globalization: Bringing Society Back In, edited by Dan Kalb , Marco van der Land, Richard Staring, Bart van Steenbergen, and Nico Wilterdink . 253-270. New York: Rowman and Littlefield, 2000.

Rahemipour, Jacqueline . "Every end is a new beginning." The Mail Archive. Accessed June 20, 2013. http://mail-archive.com/dev@native-lang.openoffice.org/msg04865.html, 2010. Raymond, Eric . "A Brief History of Hackerdom." In Opensources: Voices from the Open Source Revolution, edited by Chris DiBona, Sam Ockman , and Mark Stone , 19-29. Beijing: O'Reilly \& Associates, Inc, 1999.

Robles, Gregorio, Santiago Dueñas and Jesús M. González-Barahona . "Corporate Involvement of Libre Software: Study of Presence in Debian Code over Time." In IFIP International Federation for Information Processing, 234, Open Source Development, Adoption and Innovation, edited by J. Feller, Fitzgerald, B. , Scacchi, W. , Silitti, A. , 121-132. Boston: Springer, 2007. 
Robles, Gregorio , Jesús M. González-Barahona and M. Michlmayr . "Evolution of volunteer participation in libre software projects: Evidence from Debian." In Proceedings of the First International Conference on Open Source Systems, edited by M. Scotto and G. Succi , 100-107. Genova: University of Genova, 2005.

Robles, Gregorio and Jesús M. González-Barahona . "A comprehensive study of software forks: Dates, reasons and outcomes." IFIP Advances in Information and Communication Technology 378 (2012): 1-14.

Rohter, Larry . "Gilberto Gil Hears the Future, Some Rights Reserved." The New York Times, March 11, 2007.

Rosencrans, Nick . "Usability Evaluation Summary Report." Office of Information Technology Usability Services, University of Minnesota, 2011.

Rousseff, H.E. Dilma . Statement at the Opening of the General Debate of the 68th Session of the United Nations General Assembly, 2013.

Sassen, Saskia . "Electronic Markets and Activist Networks: The Weight of Social Logics in Digital Formations." In Digital Formations: IT and New Architectures in the Global Realm, edited by Robert Latham and Saskia Sassen , 54-88. Princeton: Princeton University Press, 2005.

Sauvant, Karl P. Trade and Foreign Direct Investment in Data Services. Boulder, CO: Westview Press, 1984.

Scally, Derek . "De-Google your life: It's worth the hassle if you value your privacy." Irish Times, May 14. Accessed February 22, 2017. http://irishtimes.com/business/technology/degoogleyour-life-it-s-worth-the-hassle-if-you-value-your-privacy-1.2211355, 2015.

Schoonmaker, Sara . "Technological Dependency in Brazil: New Terms for Power and Resistance." PhD diss., Boston College, 1990.

Schoonmaker, Sara . "Trading on-line: Information flows in advanced capitalism." The Information Society 9 (1993): 39-49.

Schoonmaker, Sara . "Capitalism and the Code: A Critique of Baudrillard's Third-Order Simulacrum." In Baudrillard: A Critical Reader, edited by Douglas Kellner , 168-188. Cambridge: Basil Blackwell, 1994.

Schoonmaker, Sara . High-Tech Trade Wars: USA-Brazilian Conflicts in the Global Economy. Pittsburgh, University of Pittsburgh Press, 2002.

Schoonmaker, Sara . "Globalization from Below: Free software and alternatives to neoliberalism." Development and Change 38 (2007): 6, 999-1020.

Schoonmaker, Sara . "Software politics in Brazil: Toward a political economy of digital inclusion." Information, Communication \& Society 12 (2009): 4, 548-565.

Schoonmaker, Sara and Pierre-Amiel Giraud. "French software politics: Activism and the dynamics of globalization from below." Revista Eletrônica de Sistemas de Informação 12 (2014): 3.

Schor, Juliet B. Plenitude: The New Economics of True Wealth. New York: Penguin, 2010.

Schor, Juliet B and Craig J. Thompson . "Introduction: Practicing Plenitude." In Sustainable Lifestyles and the Quest for Plenitude: Case Studies of the New Economy, edited by Juliet B. Schor and Craig J. Thompson , 1-25. New Haven: Yale University Press, 2014.

Schor, Juliet B and Craig J. Thompson, eds. Sustainable Lifestyles and the Quest for Plenitude: Case Studies of the New Economy. New Haven: Yale University Press, 2014. Schulz, Charles-H. "Give up spoon-feeding: Use a fork instead." September 28. Accessed November 1, 2010. http://standardsandfreedom.net/index.php/2010/09/28/give-up-spoonfeeding-use-a-fork-instead/, 2010.

Schweik, Charles M. and Robert C. English , eds. Internet Success: A Study of Open-Source Software Commons. Cambridge, MA: MIT Press, 2012.

Scollan, Becca, Abby Byrnes, Malia Nagle, Paul Coyle, Cynthia York, and Maleka Ingram . "Drupal Usability Research Report." Interaction Design \& Information Architecture, University of Baltimore, 2008.

Seidman, Stephen B. "The Role of Professional Societies in the Emergence of Software Engineering Professionalism in the United States and Canada." In IFIP International Federation for Information Processing, Volume 280, E-Government; ICT Professionalism and Competences; Service Science, edited by Antonino Mazzeo , Roberto Bellini , and Gianmario Motta ; 59-67. Boston: Springer, 2008. 
Selyukh, Alina . "U.S. Appeals Court Upholds Net Neutrality Rules in Full." The Two-Way: Breaking News from NPR. Accessed July 14, 2017. http://npr.org/sections/thetwoway/2016/06/14/471286113/u-s-appeals-court-holds-up-net-neutrality-rules-in-full, 2016. Sharwood, Simon . "Libre Office comes to Android." The Register, May 29. Accessed January 23, 2016. http://theregister.co.uk/2015/05/29/libre_office_comes_to_android/, 2015. Shaw, Aaron . "Insurgent expertise: The politics of free/livre and open source software in Brazil." Journal of Information Technology and Politics 8 no. 3 (2011): 253-272.

Sheehan, Kerry . "Trump and his advisors on net neutrality." Accessed March 24, 2017. https://eff.org/deeplinks/2016/12/trump-and-his-advisers-net-neutrality, 2016.

Sneddon, Joey . "Ubuntu 18.04 to ship with GNOME desktop, not unity." OMG! Ubuntu! Accessed July 30, 2017. http://omgubuntu.co.uk/2017/04/ubuntu-18-04-ship-gnome-desktopnot-unity, 2017.

Snowden, Edward . "The last lighthouse: Free software in dark times." Keynote address at LibrePlanet, Cambridge, MA, March 19-20. Accessed March 2, 2017.

https://media.libreplanet.org/u/libreplanet/m/libreplanet-2016-the-last-lighthouse-3d51/, 2016. Söderberg, Johan . Hacking Capitalism: The Free and Open Source Software Movement, Routledge, New York, 2008.

Spreeuwenberg, Kimberley and Thomas Poell . "Android and the political economy of the mobile Internet: A renewal of open source critique." First Monday 17 (2012): 7. Accessed July 28, 2015. http://firstmonday.org/ojs/index.php/fm/article/view/4050/3271.

Shiva, Vandana . Protect or Plunder? Understanding Intellectual Property Rights. London: Zed Books, 2001.

Steinmetz, Kevin F. Hacked: A Radical Approach to Hacker Culture. New York: New York University Press, 2016.

Takhteyev, Yuri . Coding Places: Software Practice in a South American City. Cambridge, MA: The MIT Press, 2012.

Terranova, Tiziana . "Digital Labor." In Digital Labor: The Internet as Playground and Factory, edited by Trebor Scholz , 33-57. New York: Routledge, 2013.

The Document Foundation . Progress Report about 2013 Fiscal Year. Berlin: The Document Foundation, 2013.

The Document Foundation . 2014 Annual Report. Berlin: The Document Foundation, 2014. The Document Foundation . 2015 Annual Report. Berlin: The Document Foundation, 2015a. The Document Foundation . Next Decade Manifesto. Accessed December 29. http://wiki.documentfoundation.org/TDF/Next_Decade_Manifesto, 2015b.

The H Open. "Oracle wishes LibreOffice the best, but won't directly cooperate." The H Open, 5 October, 2010.

Tigre, Paulo Bastos. Technology and Competition in the Brazilian Computer Industry. New York: St. Martin's Press, 1983.

Turkle, Sherry . Reclaiming Conversation: The Power of Talk in a Digital Age. New York: Penguin Press, 2015.

United Nations Centre on Transnational Corporations (UNCTC) . Transnational Corporations and Transborder Data Flows and Brazil. New York: United Nations, 1982.

United Nations Centre on Transnational Corporations (UNCTC) . Transborder Data Flows: A Technical Paper. New York: United Nations, 1983.

United States Telecom Association, et al., " Amicus Curiae Brief in Support of Respondents on Behalf of Writers Guild of America, West, Inc.; Future of Music Coalition; and National Alliance for Media Arts and Culture." Accessed November 21, 2017.

static.politico.com/c0/2a/2917ce7e44eba011fbf229345f6, 2015.

U.S. House Committee on Commerce . Report on the Digital Millennium Copyright Act of 1998. Rept. 105-551, pt. 2. 105th Congress, 2d sess., 22 July, 1998. Washington, DC: U.S. Government Printing Office, 1998.

Vaccari, Cristian . Digital Politics in Western Democracies: A Comparative Study. Baltimore: Johns Hopkins University Press, 2013.

Vaccari, Cristian , Andrew Chadwick, and Ben O'Loughlin . "Dual screening the political: Media events, social media, and citizen engagement." Journal of Communication 65 (2015): 1041-1061. 
Varisco, Daniel Martin . "September 11: Participant webservation of the 'War on Terrorism."' American Anthropologist 104 (2002): 934-938.

Wallerstein, Immanuel. The Modern World System. New York: Academic Press, 1974.

Wallerstein, Immanuel . "States? Sovereignty? The Dilemmas of Capitalists in an Age of Transition." In States and Sovereignty in the Global Economy, edited by David A. Smith , Dorothy J. Solinger, and Steven C. Topik , 20-33. London: Routledge, 1999.

Walls, Colin . "Software in cars." Embedded. Accessed July 26, 2017.

http://embedded.com/design/operating-systems/4442406/Software-in-cars, 2016.

Wang, Xiapeng , Kuzmickaja, Ilona , Stol, Klaas-Ian , Abrahamsson, Pekka , and Brian Fitzgerald. "Microblogging in open source software development: The case of Drupal and twitter." IEEE Software 29 (2014): 2-10.

Weber, Steven . The Success of Open Source. Boston: Harvard University Press, 2004. Wigand, Rolf T. , Carrie Shipley, and Dwayne Shipley. "Transborder data flow, informatics, and national policies." Journal of Communication 34 (1984): 153-175.

Young, Robert . "Giving It Away: How Red Hat Software Stumbled across a New Economic Model and Helped Improve an Industry." In Opensources: Voices from the Open Source Revolution, edited by Chris DiBona, Sam Ockman , and Mark Stone , 113-125. Beijing: O'Reilly \& Associates, Inc, 1999. 